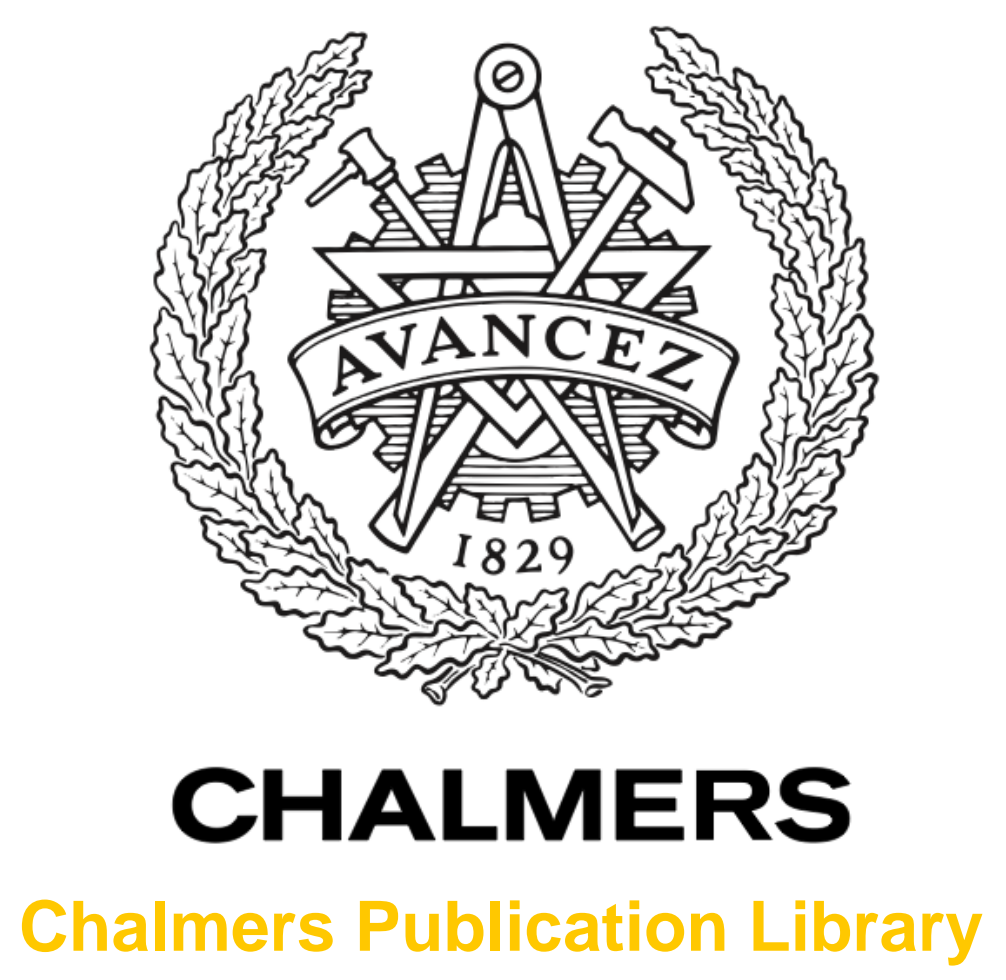

\title{
Characterization of particles from a marine engine operating at low loads
}

This document has been downloaded from Chalmers Publication Library (CPL). It is the author's version of a work that was accepted for publication in:

Atmospheric Environment (ISSN: 1352-2310)

Citation for the published paper:

Anderson, M. ; Salo, K. ; Hallquist, A. et al. (2015) "Characterization of particles from a marine engine operating at low loads". Atmospheric Environment, vol. 101 pp. 65-71.

http://dx.doi.org/10.1016/j.atmosenv.2014.11.009

Downloaded from: http://publications.lib.chalmers.se/publication/212695

Notice: Changes introduced as a result of publishing processes such as copy-editing and formatting may not be reflected in this document. For a definitive version of this work, please refer to the published source. Please note that access to the published version might require a subscription.

Chalmers Publication Library (CPL) offers the possibility of retrieving research publications produced at Chalmers University of Technology. It covers all types of publications: articles, dissertations, licentiate theses, masters theses, conference papers, reports etc. Since 2006 it is the official tool for Chalmers official publication statistics. To ensure that Chalmers research results are disseminated as widely as possible, an Open Access Policy has been adopted.

The CPL service is administrated and maintained by Chalmers Library. 


\title{
Characterization of particles from a marine engine operating at
} low loads

\author{
Maria Anderson $^{1 *}$, Kent Salo ${ }^{1}$, Åsa M. Hallquist ${ }^{2}$ and Erik Fridell ${ }^{1,2}$ \\ ${ }^{1}$ Department of Shipping and Marine Technology, Chalmers University of Technology, 41296 Gothenburg, Sweden
}

${ }^{2}$ IVL Swedish Environmental Research Institute, PO Box 5302, 40014 Gothenburg, Sweden

*Corresponding author: Maria Anderson, Department of Shipping and Marine Technology, Chalmers University of Technology, 41296 Gothenburg, Sweden; Tel: +46-31 772 2640; e-mail: maria.anderson@chalmers.se (M. Anderson)

\begin{abstract}
Particle emissions from a marine diesel engine operating at low loads with four different fuels were characterized with respect to particle number $(\mathrm{PN})$ and particle mass $(\mathrm{PM})$, size distribution, volatility and chemical composition. The four different fuels used were Swedish Environmental class 1 (MK1) and class 3 diesel (MK3), heavy fuel oil (HFO, $0.12 \mathrm{wt} \% \mathrm{~S}$ ) and marine diesel oil (MDO, $0.52 \mathrm{wt} \%$ $\mathrm{S})$. The measurements were performed for a marine diesel engine in a test-bed engine lab and the particle emissions were measured with an Engine Exhaust Particle Sizer and a Dust monitor, giving the number concentrations in the size range of 5.6-560 $\mathrm{nm}$ and $300 \mathrm{~nm}$ to $20 \mu \mathrm{m}$, respectively. To quantify the amount of solid particles a thermodenuder was used. Additionally, filter samples were taken for gravimetric, black carbon (BC) and elemental analysis. The particle emissions showed a bimodal size distribution by number and the number concentrations were dominated by nanoparticles (diameter $(\mathrm{Dp})<50 \mathrm{~nm})$. The nanoparticles measured were both primary and secondary particles, depending on fuel and engine load, while the particles with $\mathrm{Dp}>50 \mathrm{~nm}$ generally were solid primary particles. Combustion of HFO resulted in the highest PN and PM concentrations. Emission factors (EFs) for PM and PN for both the total particle emissions and the fraction of primary, solid particles are presented for different fuels and loads. $\mathrm{EFs}$ for nitrogen oxides $\left(\mathrm{NO}_{\mathrm{x}}\right), \mathrm{BC}$ and some elements $(\mathrm{Ca}$, $\mathrm{Fe}, \mathrm{V}, \mathrm{Ni}, \mathrm{Zn}$ ) are presented as well. This study contributes to understanding particle emissions from potential future fuels as well as emissions in ports and coastal areas where lower engine loads are common.
\end{abstract}

Keywords: ship emission, emission factor, nanoparticle, black carbon, low engine load, marine fuel

\section{Introduction}

Shipping is the one of the most fuel efficient means of transportation of goods and resources, but at the same time a source of air pollution to consider (Corbett, 2003). Given that around 70\% of emissions from ship operations are emitted within $400 \mathrm{~km}$ from land, ship operations can be seen as a significant source of air pollution in coastal areas (Corbett et al., 2007). In light of up-coming regulation of 


\section{The final version of this article is published in Atmospheric Environment in 2015, vol. 101 pages 65-71}

allowed sulfur (S) content in marine fuels, both within sulfur emission control areas $\left(\mathrm{SO}_{\mathrm{X}} \mathrm{ECAs}\right.$, allow $0.1 \mathrm{wt} \% \mathrm{~S}$ from 2015) and at global level ( $0.5 \mathrm{wt} \% \mathrm{~S}$ from 2020, possibly postponed to 2025), there is an interest to study how the lower sulfur content in marine fuels will affect particle emissions.

Knowledge about the size distribution of the emitted particles is important for assessments of impact on human health and fate in atmosphere. Fine particles (diameter, (Dp) $<2.5 \mu \mathrm{m}$ ) reach deeper down in the respiratory system and ultrafine particles $(\mathrm{Dp}<0.1 \mu \mathrm{m})$ may be transported further to other parts of the body with the blood (Pope and Dockery, 2006). Other properties to consider are chemical composition, number concentration and mass (Finlaysson-Pitts and Pitts, 2000). Further, the volatility of the particles may be important, since it will impact the particles ageing in the atmosphere (Salo et al., 2011).

Particles emitted from operating ships comprise of different compounds, e.g. particulate sulfate, black carbon (BC), ash and heavy metals associated to fuel and lubrication oil (Lack et al., 2009, Moldanová et al., 2009). Both fuel type and quality together with parameters related to the engine will have an impact on the character of the particle emissions (Lack et al., 2009). In aspect of particle size, solid particles from operating ships are found to peak at smaller particle sizes than particles from land-based sources, 20-40 nm and 50-100 nm respectively (Kasper et al., 2007). However, also particles with diameters of several $\mu \mathrm{m}$ have been observed in emissions from ship engines running on heavy fuel oil (HFO) (Fridell et al., 2008, Lyyränen et al., 1999). The nanoparticles (Dp <50 nm (Hinds, 1999)), are of primary and secondary origin. They consist of volatile sulfuric and organic compounds, together with compounds of solid carbon and metals, while larger particles ( $D p>50 \mathrm{~nm}$ ) are of solid character and consist of carbonaceous agglomerates with associated and absorbed species (Kittelson, 1998).

There are few studies that consider emissions of small particles, i.e. nanoparticles with respect to number concentration and size distribution, from ship engines operating at low loads e.g. manoeuvering and use low sulfur marine fuels for propulsion. Hallquist et al. (2013), Fu et al. (2013) and Moldanová et al. (2013) have performed onboard measurements that consider some of these areas. Petzold et al. (2011), Kasper et al. (2007), Ushakov et al. (2012) and Ushakov et al. (2013) present results from measurements on different test-bed engines and focus on different loads and fuel types.

The aim of this study is to characterize the particle emissions from four different fuels, when the engine is operating at lower engine loads $(\leq 35 \%)$. The fuels used were Swedish Environmental class 1 (MK1) and class 3 diesel (MK3) and HFO (0.12 wt\% S) and marine diesel oil (MDO, $0.52 \mathrm{wt} \% \mathrm{~S}$ ). MK1 and MK3 are similar with the fuels that are used for inland shipping, while and MDO are used onboard ocean-going ships. The HFO used here has lower sulfur content than the HFO normally used on ocean-going ships today. However, the sulfur content complies with limits in future regulations in $\mathrm{SO}_{\mathrm{X}}$ ECAs (0.10 wt\% S 2015) and makes it possible to study the emissions from combustion of a HFO 
The final version of this article is published in Atmospheric Environment in 2015, vol. 101 pages 65-71

with low sulfur content and investigate what other properties of the fuel that affect the particle emissions. The sulfur content of the MDO is in line with up-coming regulation of allowed sulfur content in marine fuel oils at global level $(0.5 \mathrm{wt} \% \mathrm{~S} 2020)$.

\section{Method and experimental setup}

\subsection{Experimental setup}

The measurements were conducted in a test-bed engine lab equipped with a 4-stroke, turbocharged Volvo Penta D3-110 marine diesel engine. The engine has five cylinders with a crankshaft power of $81 \mathrm{~kW}$, maximum engine speed of $3000 \mathrm{rpm}$ and is equipped with a common rail injection system. The engine is designed with four separate heated fuel tanks in order to control the viscosity of the fuel. During the experiments described here the maximum load and speed was restricted to $35 \%$ and 1750 rpm, respectively. The properties of the fuels and lubrication oils used during the two campaigns (Campaign 1 in March 2012 and Campaign 2 in October 2012) are presented in Table 1. Results for MK3 are from Campaign 1, while the other results are from Campaign 2. The HFO used here was diluted with $50 \%$ (by volume) MK1 to reduce the viscosity. According to the manufacturer, the injection system is optimized for fuels with a density of $810-860 \mathrm{~kg} / \mathrm{m}^{3}$ at $15^{\circ} \mathrm{C}$ and viscosity of 1.5 $4.5 \mathrm{cst}$ at $40^{\circ} \mathrm{C}$. The values for both viscosity and density for the studied fuels are in accordance with the limits set by the manufacturer.

Table 1: Properties of the fuels (MK1, MK3, HFO and MDO) and lubrication oils (Lub. oil 1 from campaign 1 and Lub. oil 2 from campaign 2) used in Campaigns 1 and 2. n.a stands for not analyzed.

\begin{tabular}{|c|c|c|c|c|c|c|}
\hline & MK1 & MK3 & HFO & MDO & Lub. oil 1 & Lub. oil 2 \\
\hline Aromatic content (v/v \%) & 4.4 & 15.4 & 7.7 & 18.1 & n.a & n.a \\
\hline Ash content $(\% \mathbf{m} / \mathbf{m})$ & $<0.010$ & $<0.010$ & $<0.020^{\#}$ & n.a & n.a & n.a \\
\hline Carbon residue $(\% \mathrm{~m} / \mathrm{m})$ & $<0.20$ & $<0.20$ & $<7.0^{\#}$ & n.a. & n.a & n.a \\
\hline Density at $15^{\circ} \mathrm{C}\left(\mathrm{kg} \mathrm{m}^{-3}\right)$ & 819.0 & 835.5 & $948,4^{\#}$ & 862.9 & n.a & n.a \\
\hline PAH content & $<0.02 \mathrm{v} / \mathrm{v} \%$ & $2.3 \mathrm{~m} / \mathrm{m} \%$ & $1.4 \mathrm{v} / \mathrm{v} \%$ & $3.3 \mathrm{v} / \mathrm{v} \%$ & n.a & n.a \\
\hline Viscosity (cSt) & $2.093 *$ & $2.595^{*}$ & $3.6^{+}$ & $<1-2.5^{*}$ & n.a & n.a \\
\hline Sulfur (wt\%) & $<0.0003$ & 0.0003 & 0.12 & 0.52 & n.a & n.a \\
\hline Vanadium $\left(\mathrm{mg} \mathrm{kg}^{-1}\right)$ & $<0.05$ & n.a & 1.10 & $<0.05$ & $<1$ & 1 \\
\hline Nickel $\left(\mathrm{mg} \mathrm{kg}^{-1}\right)$ & $<0.05$ & n.a & 1.10 & $<0.05$ & 1 & 1 \\
\hline Iron $\left(\mathrm{mg} \mathrm{kg}^{-1}\right)$ & 0.05 & n.a & 0.50 & 0.10 & 40 & 20 \\
\hline Calcium (mg kg ${ }^{-1}$ ) & 0.05 & n.a & 0.30 & 0.05 & 2850 & 2400 \\
\hline Zinc $\left(\mathbf{m g ~ k g}{ }^{-1}\right)$ & n.a & n.a & 0.10 & 0.40 & 1275 & 1150 \\
\hline
\end{tabular}

${ }^{\#}$ For HFO not diluted with MK1; ${ }^{*}$ viscosity at $40^{\circ} \mathrm{C} ;{ }^{+}$viscosity at $40^{\circ} \mathrm{C}$, measured with a Viscomar viscometer, MAR-TEC Marine $\mathrm{GmbH}$ 


\section{The final version of this article is published in Atmospheric Environment in 2015, vol. 101 pages 65-71}

The experimental set-up is illustrated in Figure S1. Two types of aerosol instruments were used: an Engine Exhaust Particle Sizer (EEPS, Model 3090, TSI Inc.) measuring particles in the size range of 5.6-560 nm; and a Dust Monitor (Model 1.108, Grimm) measuring particles in the size range from 300 $\mathrm{nm}$ to over $20 \mu \mathrm{m}$ in diameter. The EEPS classifies the particles after their differential electrical mobility and the Grimm uses light scattering technology to count the number of particles and classify into different sizes (TSI, 2006, Grimm Aerosol Technik GmbH \& Co KG, 2010). The instruments were measuring simultaneously and were connected directly to the dilution system (FPS, Model 4000, Dekati) and the raw exhaust was diluted in two steps. The primary dilution occurred in a perforated tube with preheated, clean and dry air $\left(300-315^{\circ} \mathrm{C}\right.$, i.e. the temperature of the raw exhaust gas). The secondary dilution used clean air of ambient temperature to dilute the sample and an ejector diluter drew the sample from the primary dilution section. According to the manufacturer the residence time in the system is below 0.5 seconds (Dekati., 2010). Table S1 presents data about the dilution ratios and dilution conditions during the measurements. To quantify the non-volatile fraction of emitted particles, i.e. primary solid particles, a thermodenuder (TD, Dekati), heated to $300^{\circ} \mathrm{C}$ was used.

For most experiments, except for MK1 (all loads) and MDO (35\% load), the FPS was connected to the exhaust gas pipe with a heated tube (held at $300-315^{\circ} \mathrm{C}$ ). For MK1 (all loads) and MDO (35\% load) the FPS was connected directly on the exhaust gas pipe. The aerosol samples were extracted under isokinetic conditions using a fixed inlet (Apex instruments) adapted to the exhaust and sampling flows (Hinds, 1999). Additionally, samples on Teflon filters were collected at 35\% engine load for each fuel type for subsequent gravimetric (total suspended particles (TSP)), BC and elemental analysis. The BC content was determined with a visible light reflectometer that is a part of the beta gauge monitor FH62 I-N (ESM Emberline, Germany) (Pettersson et al., 2011). For the elemental analysis Energy Dispersive X-Ray Fluorescence (EDXRF) was used (Boman, 2009).

During Campaign 2 gaseous compounds: nitrogen monoxide $(\mathrm{NO})$, nitrogen oxides $\left(\mathrm{NO}_{\mathrm{x}}\right)$, sulfur dioxide $\left(\mathrm{SO}_{2}\right)$, carbon monoxide $(\mathrm{CO})$, carbon dioxide $\left(\mathrm{CO}_{2}\right)$ and oxygen $\left(\mathrm{O}_{2}\right)$ were measured with an infrared gas analyzer (Fuji Electric Model ZRE NDIR-analyzer, Fuji Electric Systems Co, Ltd, Japan). In addition during Campaign 2, the concentration of NO was measured after the FPS using a chemiluminescence instrument (TH42i, Thermo Scientific) for verification of the dilution ratio. In Campaign 1, the dilution ratio reported by the FPS was corrected with a correction factor (1.29). This correction factor was the same for all loads and the DR for $10 \%$ and idle might be overestimated since the measurements in Campaign 2 indicated a variation of the correction factor with load. The factor was calculated from experiments with the FPS and $\mathrm{NO}_{\mathrm{X}}$, in which calibration gas of $\mathrm{NO}_{\mathrm{X}}(880 \mathrm{ppm})$ was lead through the FPS and the concentration of $\mathrm{NO}_{\mathrm{X}}$ was measured after dilution. The dilution conditions were similar to the conditions during the particle measurements. 
The final version of this article is published in Atmospheric Environment in 2015, vol. 101 pages 65-71

\subsection{Test cycle}

The measurements were conducted at an engine load of 10\%, 25\% and 35\% of maximum continuous rate (MCR), with an engine speed of $1750 \mathrm{rpm}$ and at idle. The engine was working on each load for 30-40 minutes and the test cycle was repeated twice for each fuel type in order to test the repeatability. Measurements at each load were conducted both with and without a thermodenuder (TD) for determining the thermal characteristics of the particles.

\subsection{Data analysis}

To ensure stable conditions during sampling, the last five minutes of each experimental setting were used for the data analysis and calculations of data from measurements with the EEPS and Grimm. The data were corrected for the dilution ratio used and size dependent particle losses within the TD were accounted for following instructions from the manufacturer. Data from measurements using the heated tube were also corrected for losses in the tube. Data from analyses of the filters were corrected for dilution ratio, not for losses of particles in the heated tube.

Particle emission factors by mass $\left(\mathrm{EF}_{\mathrm{PM}}\right)$ were calculated in two different ways. First, from particles sampled on filters $\left(\mathrm{EF}_{\mathrm{TSP}}\right)$ according to IMO (2009) (Table 3) and secondly from the mass concentration measured with the EEPS (5.6-560 nm) assuming spherical particles with unit density (Tables 2 and 4). 95\% confidence intervals (CI) to each mean value in Tables 2 and 4 was calculated. $\mathrm{EF}_{\mathrm{NOx}}$ were calculated following the IMO $\mathrm{NO}_{\mathrm{x}}$ Technical Code (IMO, 2009).

\section{Results and discussion}

\subsection{HFO}

Table 2 presents total particle number (PN) and particle mass (PM) concentrations measured during combustion of HFO. An engine load of 35\% resulted in the lowest and idle in the highest PN concentration, i.e. increased with reduced loads, as also found by Petzold et al. (2011). This may be due to reduced temperatures in the exhaust at low loads, causing unburnt fuel and oil to nucleate and form new particles, i.e. secondary particles, and also to condense on existing particles (Kittelson, 1998). For PM concentration no clear relation with load was found. An engine load of $35 \%$ resulted in the highest PM concentration, two times higher than PM at idle (Table 2). Nanoparticles were the dominating fraction in the total PN concentration (85-99.9\%, lowest number for 35\% load), while Dp $>50 \mathrm{~nm}$ dominated the PM concentrations. Similar results were found by Ushakov et al. (2012). The measurements of PN and PM concentrations with the Grimm showed that the emissions contained low concentrations of particles in the size range $300 \mathrm{~nm}$ to over $20 \mu \mathrm{m}$ (PN: $2.2-29 * 10^{4} / \mathrm{cm}^{3}$ and PM: 593$\left.7065 \mu \mathrm{g} / \mathrm{m}^{3}\right)$. 
The final version of this article is published in Atmospheric Environment in 2015, vol. 101 pages 65-71

Table 2: $P N$ and PM concentrations together with emission factors (EFs) by number and mass for total particle emission, without (wo) TD, and the solid fraction, with (w) TD, for HFO at each load. Values are calculated for particles with Dp 5.6-560 nm. A 95\% CI for each mean value is presented like mean \pm X.

\begin{tabular}{|c|c|c|c|c|c|c|c|c|}
\hline $\begin{array}{l}\text { Fuel } \\
\text { type }\end{array}$ & $\begin{array}{l}\text { Load } \\
\text { (\% of MCR) }\end{array}$ & $\begin{array}{l}\text { PN } \\
\left(10^{8} \# \mathrm{~cm}^{-3}\right)\end{array}$ & $\begin{array}{l}\text { PM } \\
\left(10^{4} \mu \mathrm{g} \mathrm{m}^{-3}\right)\end{array}$ & $\begin{array}{l}\mathbf{E F}_{\mathrm{PM}} \\
\left(\mathrm{g} \mathrm{kg}^{-1}\right)\end{array}$ & $\begin{array}{l}\mathbf{E F}_{\mathrm{PM}} \\
\left(\mathrm{g} \mathrm{kWh}^{-1}\right)\end{array}$ & $\begin{array}{l}\mathbf{E F}_{\mathrm{PN}} \\
\left(10^{16} \# \mathrm{~kg}^{-1}\right)\end{array}$ & $\begin{array}{l}\mathbf{E F}_{\mathrm{PN}} \\
\left(10^{16} \# \mathbf{k} \mathbf{W h}^{-1}\right)\end{array}$ & $\begin{array}{l}\mathbf{E F}{ }_{\mathrm{PN}} \\
\left(10^{16} \# h^{-1}\right)\end{array}$ \\
\hline \multirow[t]{8}{*}{ HFO } & 35 wo TD & $3.07 \pm 0.053$ & $11.9 \pm 0.63$ & $2.63 \pm 0.14$ & $0.65 \pm 0.03$ & $0.68 \pm 0.012$ & $0.17 \pm 0.003$ & $5.1 \pm 0.087$ \\
\hline & 35 w TD & $2.24 \pm 0.097$ & $5.62 \pm 1.39$ & $1.25 \pm 0.31$ & $0.31 \pm 0.08$ & $0.50 \pm 0.022$ & $0.12 \pm 0.005$ & $3.7 \pm 0.16$ \\
\hline & 25 wo TD & $251 \pm 0.74$ & $10.8 \pm 1.72$ & $2.57 \pm 0.41$ & $0.71 \pm 0.11$ & $60 \pm 0.18$ & $17 \pm 0.059$ & $382 \pm 1.13$ \\
\hline & 25 w TD & $2.52 \pm 0.046$ & $8.10 \pm 0.50$ & $1.94 \pm 0.12$ & $0.53 \pm 0.033$ & $0.60 \pm 0.011$ & $0.17 \pm 0.003$ & $3.83 \pm 0.07$ \\
\hline & 10 wo TD & $78.9 \pm 0.26$ & $3.05 \pm 0.17$ & $0.82 \pm 0.046$ & $0.45 \pm 0.025$ & $21 \pm 0.07$ & $12 \pm 0.04$ & $107 \pm 0.36$ \\
\hline & $10 \mathrm{w}$ TD & $2.09 \pm 0.032$ & $3.23 \pm 0.20$ & $0.87 \pm 0.05$ & $0.48 \pm 0.03$ & $0.56 \pm 0.009$ & $0.31 \pm 0.005$ & $2.8 \pm 0.043$ \\
\hline & 0 wo TD & $432 \pm 1.83$ & $6.43 \pm 0.27$ & $1.98 \pm 0.083$ & - & $133 \pm 0.57$ & - & $230 \pm 0.97$ \\
\hline & 0 w TD & $4.50 \pm 0.034$ & $2.57 \pm 0.13$ & $0.79 \pm 0.04$ & - & $1.4 \pm 0.011$ & - & $2.4 \pm 0.019$ \\
\hline
\end{tabular}

Table 3 presents $\mathrm{EFs}$ for $\mathrm{NO}_{\mathrm{x}}, \mathrm{TSP}, \mathrm{BC}$ and five inorganic compounds at $35 \%$ engine load for combustion of $\mathrm{HFO}$. The calculated value of $\mathrm{EF}_{\mathrm{PM}}$ in $\mathrm{g} / \mathrm{kWh}$ at $35 \%$ load, from measurements with the EEPS (Table 2) is considerably higher than $\mathrm{EF}_{\mathrm{TSP}}$ in $\mathrm{g} / \mathrm{kWh}$ from filter measurements (Table 3). This emphasizes the differences between sampling methods, the uncertainty an assumption of unity density causes and that volatile species may evaporate during filter sampling, which is particularly important for HFO (Kasper et al., 2007). In reality the density will differ significantly from unity and may vary with particles size (Barone et al. (2011), Ahlvik et al. (1998), Park et al. (2003), Virtanen et al. (2002)). $\mathrm{EF}_{\mathrm{TSP}}$ in Table 3 is in line with $\mathrm{EFs}$ for maneuvering ships reported by Winnes and Fridell (2010), $0.11 \mathrm{~g} / \mathrm{kWh}$ compared to $0.16-0.23 \mathrm{~g} / \mathrm{kWh}$ from combustion of HFO (0.49 wt $\% \mathrm{~S}$ ). Other values from literature of $\mathrm{EF}_{\mathrm{PM}}$ for low loads are 0.423 and $1.009 \mathrm{~g} / \mathrm{kWh}$ for $\mathrm{HFO}(2.17 \mathrm{wt} \% \mathrm{~S})$ at 25 and $10 \%$ load respectively (Petzold et al., 2011). The higher values can be related to a higher sulfur content of the fuel in Petzold et al. (2011). It should be noted that it is difficult to compare results from measurements on different engine types with e.g. different injection systems. Measured $\mathrm{EF}_{\mathrm{BC}}$ was 110 $\mathrm{mg} / \mathrm{kg}$ fuel and the elemental analysis showed high concentrations of $\mathrm{V}$ and $\mathrm{Ni}$, known tracers for HFO (Isakson et al., 2001, Popovicheva et al., 2009, Mazzei et al., 2008). Other elements found were $\mathrm{Fe}, \mathrm{Ca}$ and $\mathrm{Zn}$ that mainly origin from the lubrication oil.

Table 3: $E F_{T S P}, E F_{N O X}, E F_{B C}$ and $E F$ for inorganic compounds at $35 \%$ load from particles sampled on filter.

\begin{tabular}{l|llll} 
& MK1 & MK3 & HFO & MDO \\
\hline $\mathrm{EF}_{\mathrm{TSP}}\left(\mathrm{g} \mathrm{kWh}^{-1}\right)$ & 0.02 & 0.014 & 0.11 & 0.016 \\
$\mathrm{EF}_{\mathrm{TSP}}\left(\mathrm{g} \mathrm{kg}^{-1}\right)$ & 0.09 & 0.06 & 0.47 & 0.06 \\
$\mathrm{EF}_{\mathrm{NOx}}\left(\mathrm{g} \mathrm{kWh}^{-1}\right)$ & 7.0 & 6.4 & 7.2 & 7.8
\end{tabular}


The final version of this article is published in Atmospheric Environment in 2015, vol. 101 pages 65-71

\begin{tabular}{l|llll}
$\mathrm{EF}_{\mathrm{BC}}\left(\mathrm{mg} \mathrm{kg}^{-1}\right)$ & 30 & 10 & 110 & 10 \\
$\mathrm{EF}_{\mathrm{Ca}}\left(\mathrm{mg} \mathrm{kg}^{-1}\right)$ & - & - & 0.31 & - \\
$\mathrm{EF}_{\mathrm{Fe}}\left(\mathrm{mg} \mathrm{kg}^{-1}\right)$ & 0.71 & 0.06 & 1.12 & 0.11 \\
$\mathrm{EF}_{\mathrm{V}}\left(\mathrm{mg} \mathrm{kg}^{-1}\right)$ & - & 0.02 & 0.40 & - \\
$\mathrm{EF}_{\mathrm{Ni}}\left(\mathrm{mg} \mathrm{kg}^{-1}\right)$ & 1.0 & - & 0.52 & 0.04 \\
$\mathrm{EF}_{\mathrm{Zn}}\left(\mathrm{mg} \mathrm{kg}^{-1}\right)$ & 0.51 & 0.21 & 0.35 & 0.26 \\
\hline
\end{tabular}

*Sampled without the heated tube

The particle size distribution by number for HFO and the distillates are shown in Figure 1a-d. For HFO (circles) a pronounced peak at 6-10 nm was found for all loads. At 35\% load a pronounced peak at $100-110 \mathrm{~nm}$ was also found. This peak was not significantly changed with reduced load, however, the peak for smaller particles became wider and the bimodal size distribution became less pronounced. Similar trends were also seen for particles of non-volatile character, i.e. solid primary particles (Figure 2a-d). At 35\% engine load a bimodal character of the number size distribution was found with distinct peaks at around $10 \mathrm{~nm}$ and at 100-110 nm (Figure 2a). The peak at 100-110 nm for the solid particles became less distinct with reduced load. A comparison of the size distributions in Figure 2a-d and data in Table S2 indicate that particles with $\mathrm{Dp}>50 \mathrm{~nm}$ were mainly solid, primary particles while the nanoparticles were both primary and secondary particles. For loads below 35\% (Figure 2b-d), the major part of particles lost in the TD, i.e. volatile, secondary particles, was in the size range of nanoparticles. Measured data of PN and PM concentrations indicate as well a considerable fraction of volatile particles in the emissions from combustion of HFO.

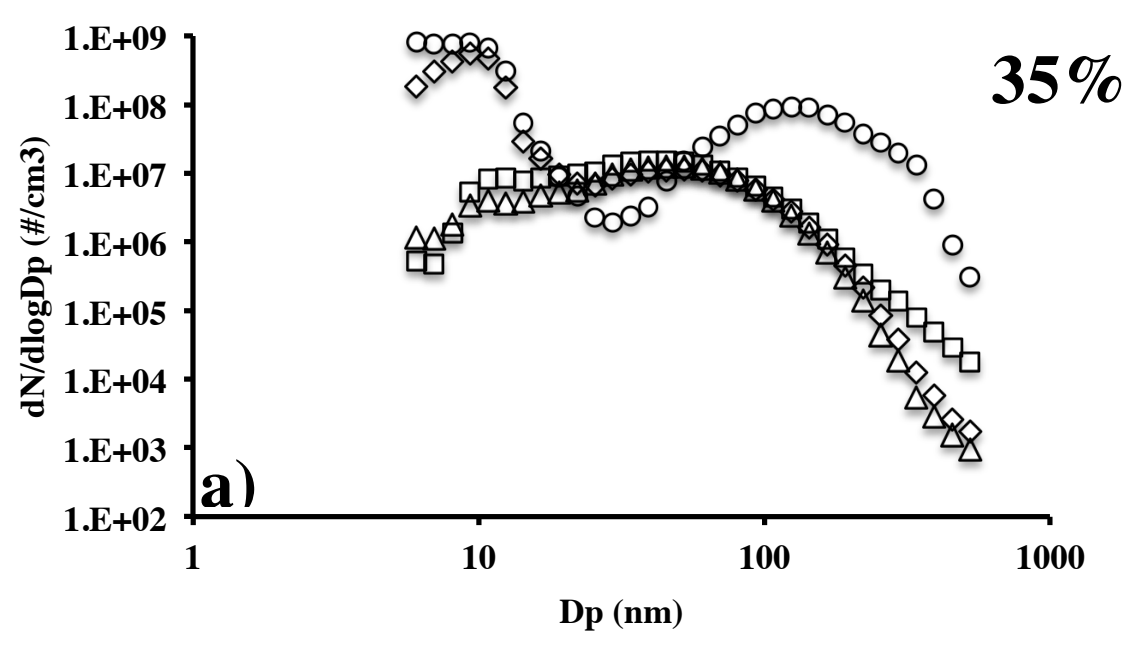


The final version of this article is published in Atmospheric Environment in 2015, vol. 101 pages 65-71
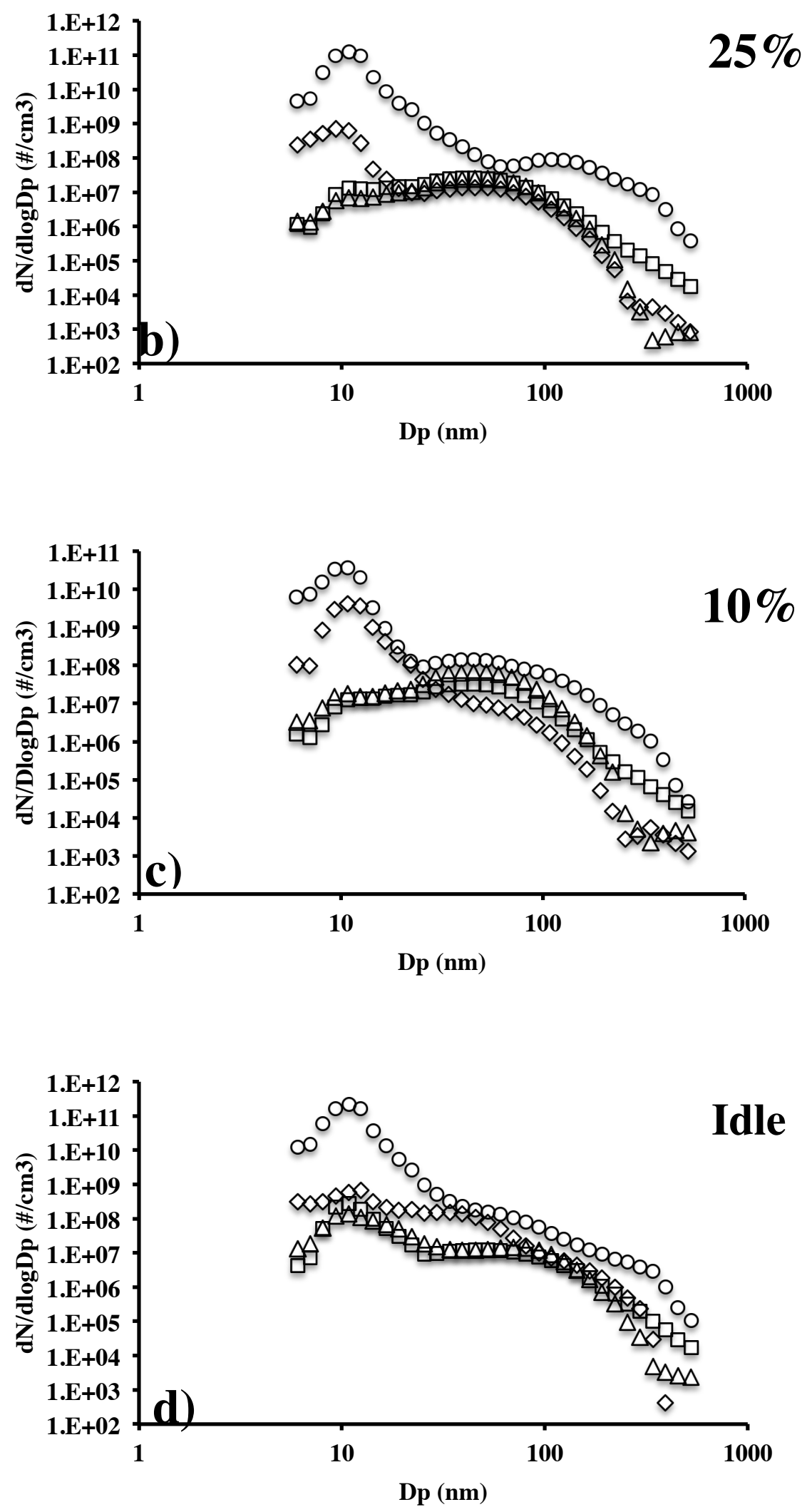

Figure 1: Number size distributions for measured particles (5.6-560 nm) for a) 35\% load, b) 25\% load, c) 10\% and d) idle and four different fuel types; MK1 (triangles), MK3 (squares), HFO (circles) and MDO (diamonds). 
The final version of this article is published in Atmospheric Environment in 2015, vol. 101 pages 65-71

\subsection{Distillate fuels}

The three distillates investigated were MDO (0.52 wt\% S), MK1 $(<0.0003 \mathrm{wt} \% \mathrm{~S})$ and MK3 $(0.0003$ wt\% S). PN and PM concentrations and emission factors (EFs) for each load and fuel type are presented in Table 4. In comparison to HFO, the three distillates resulted in lower total PN and PM emissions and consequently also lower $\mathrm{EF}_{\mathrm{PN}}$ and $\mathrm{EF}_{\mathrm{PM}}$. $\mathrm{MDO}$ resulted in the highest values of the three distillates while the order for MK1 and MK3 varied with load. The total PN concentrations, at different loads, for MDO were between $0.3-46 \%$ of PN for HFO. For MK1 the corresponding number were $0.1-3.0 \%$ and for MK3 $0.1-4.0 \%$. Similar to HFO, the total PN concentration, in general, increased with decreased load. For both MK1 and MK3 the highest values were found during idle, while for MDO the highest value was found for $10 \%$ load. Total PM concentrations for the distillates were lower compared to HFO, which is in line with other studies (Kasper et al., 2007, Petzold et al., 2011) and is suggested to depend on an increase of the amount of organic soluble fraction and residue fraction in particles from HFO (Kasper et al., 2007). The emitted particle masses from MDO were 0.9$7.9 \%$ of the mass of particles from HFO. The corresponding number for MK1 and MK3 were 1.2$15.7 \%$ and $1.9-4.8 \%$, respectively. The PM concentrations for MDO were in the same range or lower compared to MK1 and MK3 at all loads, except for idle where MDO resulted in higher PM concentration compared to the other two distillates. These results indicate that the PM concentration is more dependent on other fuel properties than the sulfur content in the fuel. These other fuel properties may be viscosity, content of metals, flash point and carbon residue, which are considerably higher for HFO than for the distillates. In contrast to what was observed for the PN concentrations, no clear relationship between engine load and PM concentration was found. This may be influenced by that the engine is equipped with a common rail system, which continues to have a high injection pressure even at lower loads.

Table 4: PN and PM concentrations and EFs by number and mass for total particle emission, without (wo) TD and the solid fraction, with (w) TD, for MK1, MK3 and MDO at each load. Values are calculated for particles with Dp 5.6-560 nm. A 95\% CI for each mean value is presented like mean $\pm X$.

\begin{tabular}{|c|c|c|c|c|c|c|c|c|}
\hline $\begin{array}{l}\text { Fuel } \\
\text { type }\end{array}$ & $\begin{array}{c}\text { Load } \\
\text { (\% of } \\
\text { MCR) }\end{array}$ & $\begin{array}{c}\text { PN } \\
\left(10^{7} \# \mathrm{~cm}^{-3}\right)\end{array}$ & $\begin{array}{c}\text { PM } \\
\left(10^{3} \mu \mathrm{g} \mathrm{m}^{-3}\right)\end{array}$ & $\begin{array}{c}\mathbf{E F}_{\mathrm{PM}} \\
\left(10^{-2} \mathrm{~g} \mathrm{~kg}^{-1}\right)\end{array}$ & $\begin{array}{c}\mathbf{E F}_{\mathrm{PM}} \\
\left(* 10^{-2} \mathrm{~g} \mathrm{kWh}^{-1}\right)\end{array}$ & $\begin{array}{c}\mathbf{E F}_{\mathrm{PN}} \\
\left(10^{14} \# \mathrm{~kg}^{-1}\right)\end{array}$ & $\begin{array}{c}\mathbf{E F}_{\mathbf{P N}} \\
\left(10^{14} \#\right. \\
\left.\mathbf{k} \mathbf{W h}^{-1}\right)\end{array}$ & $\begin{array}{c}\mathbf{E F}_{\mathrm{PN}} \\
\left(10^{14} \# \mathbf{h}^{-1}\right)\end{array}$ \\
\hline \multirow[t]{7}{*}{ MK1 } & $\begin{array}{l}35 \text { wo TD } \\
35 \text { wD }\end{array}$ & $\begin{array}{l}0.91 \pm 0.20 \\
0.89 \pm 0.12\end{array}$ & $\begin{array}{l}1.37 \pm 0.19 \\
1.29 \pm 0.15\end{array}$ & $\begin{array}{l}3.43 \pm 0.47 \\
3.21 \pm 0.40\end{array}$ & $\begin{array}{l}0.77 \pm 0.11 \\
0.76 \pm 0.08\end{array}$ & $\begin{array}{l}2.3 \pm 0.349 \\
2.2 \pm 0.31\end{array}$ & $\begin{array}{c}0.51 \pm 0.11 \\
0.50 \pm 0.069\end{array}$ & $\begin{array}{l}15.6 \pm 3.36 \\
15.3 \pm 2.11\end{array}$ \\
\hline & 25 wo TD & $1.67 \pm 0.30$ & $2.05 \pm 0.14$ & $6.23 \pm 0.42$ & $1.40 \pm 0.09$ & $5.1 \pm 0.89$ & $1.1 \pm 0.2$ & $26.0 \pm 4.56$ \\
\hline & 25 w TD & $1.57 \pm 0.17$ & $1.73 \pm 0.09$ & $5.27 \pm 0.27$ & $1.18 \pm 0.06$ & $4.8 \pm 0.52$ & $1.07 \pm 0.12$ & $24.4 \pm 2.68$ \\
\hline & 10 wo TD & $4.23 \pm 0.69$ & $4.77 \pm 0.24$ & $20.0 \pm 1.01$ & $6.82 \pm 0.35$ & $17.7 \pm 2.87$ & $6.05 \pm 0.98$ & $56.5 \pm 9.18$ \\
\hline & 10 w TD & $4.02 \pm 0.40$ & $3.76 \pm 0.17$ & $15.7 \pm 0.70$ & $5.37 \pm 0.24$ & $16.8 \pm 1.67$ & $5.74 \pm 0.57$ & $53.7 \pm 5.34$ \\
\hline & O wo TD & $5.21 \pm 1.47$ & $2.68 \pm 0.26$ & $19.6 \pm 1.87$ & - & $38.1 \pm 10.8$ & - & $28.1 \pm 7.94$ \\
\hline & 0 w TD & $2.83 \pm 0.34$ & $2.65 \pm 0.13$ & $19.3 \pm 0.93$ & - & $20.7 \pm 2.49$ & - & $15.2 \pm 1.83$ \\
\hline \multirow[t]{2}{*}{ MK3 } & $\begin{array}{l}35 \text { wo TD } \\
35 \text { w TD }\end{array}$ & $\begin{array}{l}1.22 \pm 0.06 \\
1.12 \pm 0.06\end{array}$ & $\begin{array}{l}2.29 \pm 0.19 \\
2.02 \pm 0.24\end{array}$ & $\begin{array}{l}5.3 \pm 0.44 \\
4.7 \pm 0.50\end{array}$ & $\begin{array}{l}1.3 \pm 0.10 \\
1.1 \pm 0.10\end{array}$ & $\begin{array}{l}2.89 \pm 0.15 \\
2.61 \pm 0.14\end{array}$ & $\begin{array}{l}0.65 \pm 0.03 \\
0.62 \pm 0.03\end{array}$ & $\begin{array}{l}19.9 \pm 1.06 \\
18.3 \pm 1.00\end{array}$ \\
\hline & 25 wo TD & $1.96 \pm 0.08$ & $3.02 \pm 0.18$ & $8.27 \pm 0.49$ & $2.13 \pm 0.13$ & $5.36 \pm 0.23$ & $1.38 \pm 0.06$ & $28.0 \pm 1.21$ \\
\hline
\end{tabular}


The final version of this article is published in Atmospheric Environment in 2015, vol. 101 pages 65-71

\begin{tabular}{llllllllc} 
& 25 w TD & $1.94 \pm 0.08$ & $2.84 \pm 0.16$ & $7.80 \pm 0.44$ & $2.01 \pm 0.11$ & $5.33 \pm 0.22$ & $1.37 \pm 0.06$ & $27.8 \pm 1.14$ \\
& 10 wo TD & $2.30 \pm 0.09$ & $3.01 \pm 0.16$ & $10.88 \pm 0.57$ & $4.58 \pm 0.24$ & $8.31 \pm 0.33$ & $3.50 \pm 0.14$ & $28.5 \pm 1.12$ \\
& 10 w TD & $2.40 \pm 0.08$ & $2.52 \pm 0.14$ & $9.12 \pm 0.50$ & $3.84 \pm 0.21$ & $8.66 \pm 0.30$ & $3.64 \pm 0.13$ & $29.6 \pm 1.03$ \\
& 0 wo TD & $6.61 \pm 0.15$ & $3.07 \pm 0.27$ & $9.94 \pm 1.77$ & - & $42.9 \pm 0.97$ & - & $32.3 \pm 0.73$ \\
& 0 w TD & $7.13 \pm 0.17$ & $2.89 \pm 0.33$ & $18.76 \pm 2.16$ & - & $46.3 \pm 1.10$ & - & $34.9 \pm 0.83$ \\
\hline MDO & 35 wo TD & $14.2 \pm 4.57$ & $1.61 \pm 0.44$ & $3.56 \pm 0.96$ & $0.87 \pm 0.24$ & $31.5 \pm 10.1$ & $7.68 \pm 2.47$ & $236 \pm 75.8$ \\
& 35 w TD & $5.53 \pm 2.07$ & $1.31 \pm 0.31$ & $2.91 \pm 0.68$ & $0.71 \pm 0.16$ & $12.2 \pm 4.59$ & $2.98 \pm 1.12$ & $91.6 \pm 34.4$ \\
& 25 wo TD & $8.30 \pm 0.052$ & $1.02 \pm 0.15$ & $2.74 \pm 0.41$ & $0.67 \pm 0.10$ & $22.3 \pm 0.14$ & $5.50 \pm 0.035$ & $120 \pm 0.76$ \\
& 25 w TD & $11.3 \pm 0.048$ & $0.97 \pm 0.13$ & $2.60 \pm 0.36$ & $0.64 \pm 0.09$ & $30.3 \pm 0.13$ & $7.46 \pm 0.032$ & $164 \pm 0.69$ \\
& 10 wo TD & $67.5 \pm 0.13$ & $1.34 \pm 0.17$ & $4.63 \pm 0.59$ & $1.75 \pm 0.22$ & $234 \pm 0.46$ & $88.7 \pm 0.18$ & $829 \pm 1.64$ \\
& 10 w TD & $62.2 \pm 0.097$ & $1.11 \pm 0.12$ & $3.84 \pm 0.43$ & $1.45 \pm 0.16$ & $216 \pm 0.34$ & $81.7 \pm 0.13$ & $764 \pm 1.19$ \\
& 0 wo TD & $24.6 \pm 0.26$ & $5.06 \pm 0.36$ & $30.96 \pm 2.19$ & - & $150 \pm 1.62$ & - & $130 \pm 1.39$ \\
0 w TD & $24.6 \pm 0.16$ & $4.70 \pm 0.32$ & $28.77 \pm 1.93$ & - & $150 \pm 0.98$ & - & $130 \pm 0.85$ \\
\hline
\end{tabular}

$\mathrm{EF}_{\mathrm{TSP}}$ for the distillates were lower compared to HFO. $\mathrm{EF}_{\mathrm{BC}}$ for $\mathrm{HFO}$ was several times higher than $\mathrm{EF}_{\mathrm{BC}}$ for the distillates (Table 3), as also reported by Petzold et al. (2011). Similar with HFO there were some differences between $\mathrm{EF}_{\mathrm{TSP}}$ in $\mathrm{g} / \mathrm{kWh}$ from filter measurements (Table 3), with values of $\mathrm{EF}_{\mathrm{PM}}$ in $\mathrm{g} / \mathrm{kWh}$ at $35 \%$ load in Table 4 . For MK1 and $\mathrm{MDO}, \mathrm{EF}_{\mathrm{TSP}}$ were considerably higher than the values of $\mathrm{EF}_{\mathrm{PM}}$ calculated from $\mathrm{PN}$ concentrations with assumed unit density, while values for MK3 were in line with each other. $\mathrm{EF}_{\mathrm{NOx}}$ was within the same range for all fuels (Table 3). Regarding the content of inorganic elements in the particles, $\mathrm{Ca}$ was expected to be found in particles from all fuel types, since it is associated with the lubrication oil (Amann and Siegla, 1981). However, as presented in Table 3, Ca was only found in particles from HFO due to a higher concentration of $\mathrm{Ca}$ in HFO than in the distillates. $\mathrm{Fe}$ and $\mathrm{Zn}$ were found in particles from all distillates, with a likely origin from the lubrication oil (Table 1). A higher content of Fe in HFO or increased consumption of lubrication oil when running on $\mathrm{HFO}$ resulted in a higher $\mathrm{EF}_{\mathrm{Fe}}$ for $\mathrm{HFO}$ compared to the distillates $(0.06-0.71 \mathrm{mg} / \mathrm{kg}$ fuel compared to $1.12 \mathrm{mg} / \mathrm{kg}$ fuel). Fe together with other metals found in emitted particles, can also be a result of the wear of the engine (Stone, 2012). Despite a higher concentration of Fe in MDO, resulted combustion of MK1 in the second highest $\mathrm{EF}_{\mathrm{Fe}},(0.71 \mathrm{mg} / \mathrm{kg})$. Further, combustion of MK1 resulted in the highest $\mathrm{EF}_{\mathrm{Zn}}$ and $\mathrm{EF}_{\mathrm{Ni}}$, despite a higher concentration of $\mathrm{Ni}$ in $\mathrm{HFO} . \mathrm{EF}_{\mathrm{TSP}}$ and $\mathrm{EF}_{\mathrm{BC}}$ were as well higher for MK1 compared to the other two distillates (Table 3). $\mathrm{EF}_{\mathrm{TSP}}$ in $\mathrm{g} / \mathrm{kWh}$ for MK1 was $20 \%$ and $30 \%$ higher than the corresponding value for $\mathrm{MDO}$ and $\mathrm{MK} 3$ respectively and $\mathrm{EF}_{\mathrm{BC}}$ for MK1 was three times higher compared to $\mathrm{EF}_{\mathrm{BC}}$ for $\mathrm{MDO}$ and $\mathrm{MK} 3$, despite the similarities with MK3 and $\mathrm{MDO}$ in $\mathrm{EF}_{\mathrm{PM}}$ for the solid fraction (Table 4).

Similar to HFO, the total PN concentrations for the three distillates were dominated by nanoparticles. Dp $>50 \mathrm{~nm}$ dominated the PM concentrations and the emissions contained low concentrations of particles in the size range $300 \mathrm{~nm}$ to over $20 \mu \mathrm{m}$. Combustion of MK1 and MK3 resulted in smaller fractions of nanoparticles than from MDO (60-70\% (90-94\% for idle) compared to $94-99.8 \%$ for MDO), which is thought to be related to other properties of the fuel than just sulfur content, since a 


\section{The final version of this article is published in Atmospheric Environment in 2015, vol. 101 pages}

65-71

high amount of the nanoparticles found for MDO and HFO are solid primary particles (Figure 2). The PN concentration for larger particles (300 nm up to over $20 \mu \mathrm{m}$ ) was for MK1 393-3900/ $/ \mathrm{cm}^{3}$, for MK3 251-1780 $/ \mathrm{cm}^{3}$ and for MDO 555-2740 $/ \mathrm{cm}^{3}$. The PM concentrations varied between 14-230 $\mu \mathrm{g} / \mathrm{m}^{3}$ for MK1, 8-207 $\mu \mathrm{g} / \mathrm{m}^{3}$ for MK3 and 23-145 $\mu \mathrm{g} / \mathrm{m}^{3}$ for MDO.

MK1 (triangles) and MK3 (squares) showed similar size distributions by number: bimodal character with a minor peak around $10 \mathrm{~nm}$ and a major peak at $45-50 \mathrm{~nm}$ (Figure 1a-d). At 35\% load, MDO (diamonds) showed a major peak at $10 \mathrm{~nm}$ and a minor at 45-50 nm. Similar to HFO, the second peak at 45-50 $\mathrm{nm}$ became less pronounced with reduced load. The distillates showed small or no differences in the size distribution for particles with $\mathrm{Dp}>50 \mathrm{~nm}$. Even the PN concentration for Dp $>50 \mathrm{~nm}$ for HFO gets more in line with the other fuel types with decreased load. Still, HFO resulted in a higher PN concentration for Dp $>50 \mathrm{~nm}$. Figure 1a-d indicates that the sulfur content and other properties of the fuel mainly affect the peak around $10 \mathrm{~nm}$ (i.e. nucleation mode) and that the quality of the fuel has more impact on the size distribution for $\mathrm{Dp}>50 \mathrm{~nm}$. Bimodal size distributions were also reported by Hallquist et al. (2013), with peaks at $10 \mathrm{~nm}$ and $40 \mathrm{~nm}$ for lower loads.

The particle emissions from the three distillates mainly contained primary solid particles. The highest amounts of volatile particles were found for 35\% load for MDO and at idle for MK1 (Table S2). Similar to HFO, nanoparticles were the dominating fraction in the emissions of solid primary particles, 62-71\% for MK1 and MK3 (78\% for MK1 and 94\% for MK3 at idle) and 94-99.8\% for MDO. In general, the EFs for the solid primary particles were lower for the distillates than for HFO (Table 4 compared to Table 2), which was found by Petzold et al. (2011) as well. This implies a relation between fuel quality and emissions of solid primary particles and is indicated by Lack and Corbett (2012). The PN concentration for solid primary particles increased with engine loads below 35\% (Table 4), which is the load that the engine is tuned for and as discussed in Lack and Corbett (2012), emissions of soot/BC can be expected to increase if an engine operate outside the tuned engine load.

The size distributions by number for the solid primary particle fraction from combustion of MDO were in line with the distribution for the total PN concentration (Figure 2a-d). Peaks were found at 10 $\mathrm{nm}$ and 45-50 nm, which was also found by Kasper et al. (2007) and there was a loss of nanoparticles in the TD when operating at 35\% load (Figure 2a). When operating at lower loads the nanoparticles were mainly of solid character (Figure 2b-d) and independent of load particles with Dp $>50 \mathrm{~nm}$ were mainly solid primary particles. This is in line with the results for HFO and by Hallquist et al. (2013). 
The final version of this article is published in Atmospheric Environment in 2015, vol. 101 pages 65-71
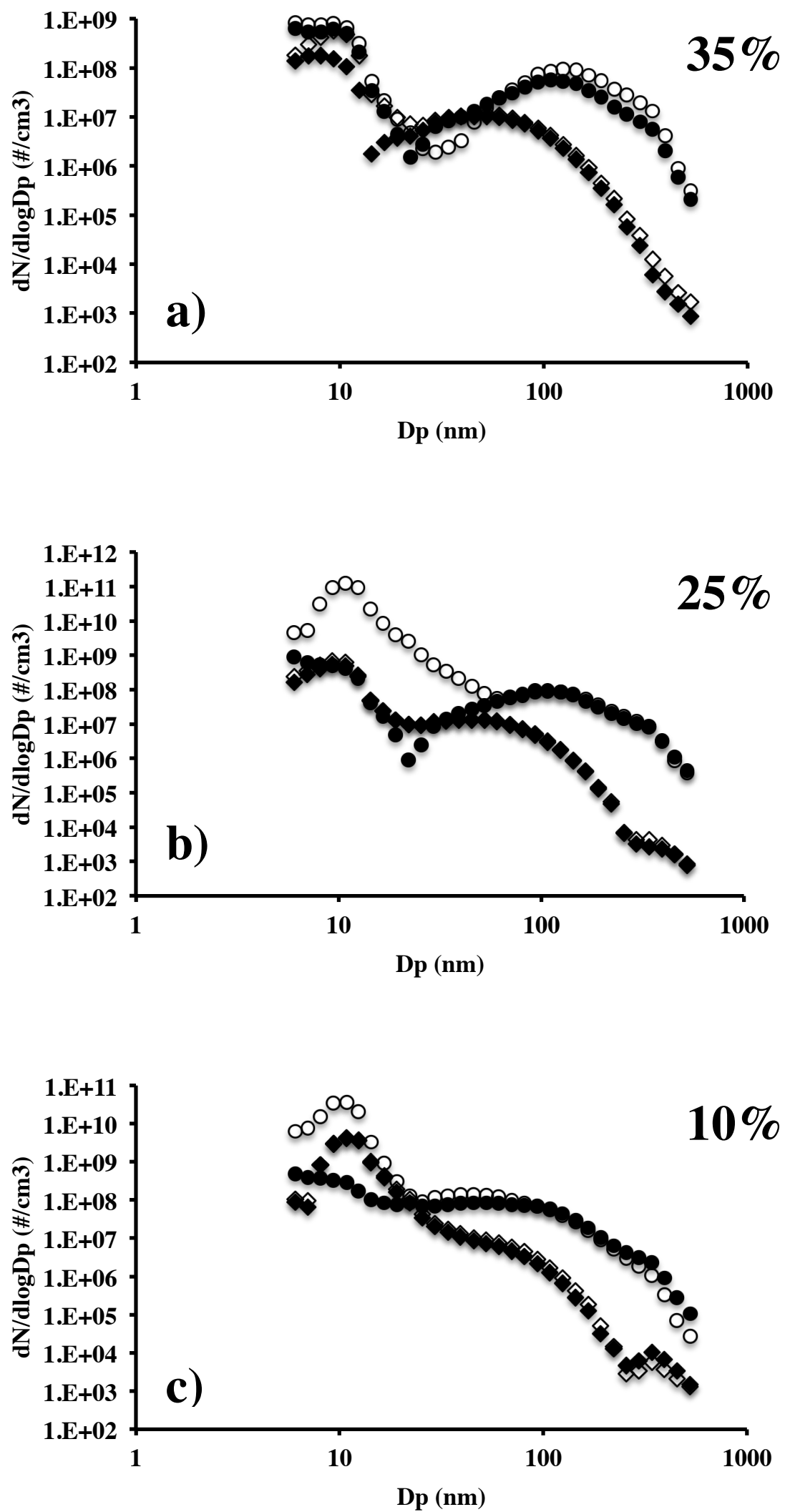


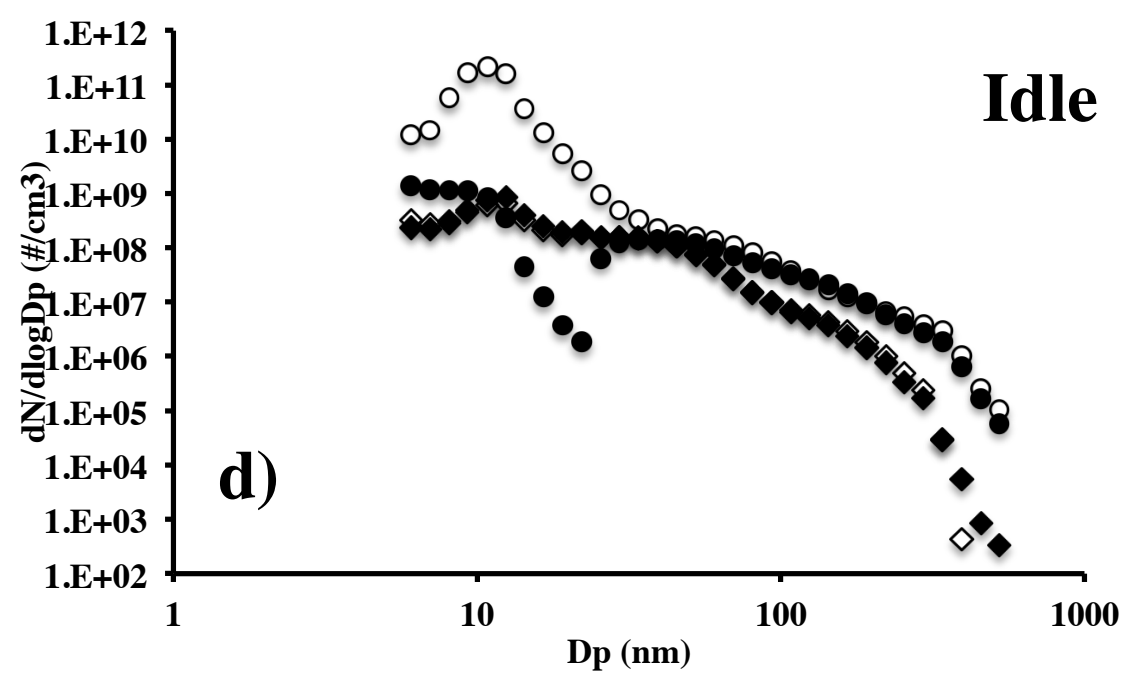

Figure 2: Number size distributions for particles in the size range 5.6-560 $\mathrm{nm}$ for HFO (circles) and MDO (diamonds) with TD (filled circles) and without TD (unfilled circles) at a) 35\% load, b) 25\% load, c) $10 \%$ load and d) at idle.

The results from this study indicate the importance of considering PN concentrations in standards and regulations, due to that nanoparticles are the dominating fraction of total PN concentration and these particles can have considerable impact on human health (Pope and Dockery, 2006). The nanoparticles have a low contribution to the $\mathrm{PM}$ concentration and $\mathrm{EF}_{\mathrm{PM}}$, which often are used in calculations and evaluation of emissions from operating ships. This point at the importance of considers both PN and PM concentrations to get a more accurate picture of the emissions. The measurements also indicate that reducing the sulfur content in marine fuels to the level of MK1 and MK3 will reduce the amount of emitted nanoparticles, but will have low impact on the emission of $\mathrm{Dp}>50 \mathrm{~nm}$ since these are mainly solid primary particles and associated to quality of the fuel rather than sulfur content. This shows that both sulfur content and quality of the fuel are to consider in regulation of particle emissions. Additionally, the results further indicated that today's regulation regarding maximum allowed sulfur content in marine fuels, when the ships operate in ports and coastal areas/SO $\mathrm{SO}_{\mathrm{x}} \mathrm{ECAs}$, are a step in the right direction to improve air quality. There is a need for further work and investigations on how to consider the emissions of solid primary particles, which like the volatile fraction have impact on both health and climate.

\section{Conclusion}

The particle emissions from four different fuels were characterized. For all fuels there were an increase of PN concentrations with decreased load, which point at the importance of consider particle emissions even in port areas when lower loads are used. Independently of fuel, bimodal size distributions by number were shown, with peaks at $10 \mathrm{~nm}$ and $45-50 \mathrm{~nm}$ for distillates and 10 and 100 $110 \mathrm{~nm}$ for HFO. The emissions of nanoparticles $(\mathrm{Dp}<50 \mathrm{~nm})$ were the dominating fraction of the 
The final version of this article is published in Atmospheric Environment in 2015, vol. 101 pages 65-71

total PN concentration and can be related to both sulfur content and other properties of the fuel. The total PM concentrations were dominated by particles with $\mathrm{Dp}>50 \mathrm{~nm}$. Particles with $\mathrm{Dp}>50 \mathrm{~nm}$ were solid primary particles and associated to the quality of the fuel. There were no or small differences between the distillates, while HFO resulted in somewhat higher emissions of $\mathrm{Dp}>50 \mathrm{~nm}$. The amounts of volatile particles in the emission were associated to sulfur content and quality of the fuel, and were mainly found in emissions from HFO and MDO and in the size range of nanoparticles. This study indicate that a reduction of sulfur in the fuels and use of more high quality fuels will decrease the emissions of nanoparticles, which have negative impact on human health and climate. It also points at the importance of handle particles with $\mathrm{Dp}>50 \mathrm{~nm}$ that are of importance as well, for both human health and climate, since even high quality fuels emits considerable amounts of these particles.

\section{Acknowledgement}

Ångpanneföreningen's Foundation for Research and Development, the Foundation for the Swedish Environmental Research Institute, SIVL, Swedish Maritime Organization and Lighthouse are acknowledged for financial support. Kjell Peterson, IVL, is gratefully acknowledged for his assistance during the two measurement campaigns. Preem is acknowledged for their support of different fuel types used in the experiments.

\section{References}

AHLVIK, P., NTZIACHRISTOS, L., KESKINEN, J. \& VIRTANEN, A. 1998. Real Time Measurements of Diesel Particle Size Distribution with an Electrical Low Pressure Impactor. SAE Technical Paper Series, 980410.

AMANN, C. A. \& SIEGLA, D. C. 1981. Diesel Particulates-What They Are and Why. Aerosol Science and Technology, 1, 73-101.

BARONE, T. L., LALL, A. A., STOREY, J. M. E., MULHOLLAND, G. W., PRIKHODKO, V. Y., FRANKLAND, J. H., PARKS, J. E. \& ZACHARIAH, M. R. 2011. Size-Resolved Density Measurements of Particle Emissions from an Advanced Combustion Diesel Engine: Effect of Aggregate Morphology. Energy \& Fuels, 25, 1978-1988.

BOMAN, J. 2009. Trace element analysis of urban aerosol particles using X-ray fluorescence spectrometry. Spectroscopy Europe, 21.

CORBETT, J. J. 2003. Updated emissions from ocean shipping. Journal of Geophysical Research, 108.

CORBETT, J. J., WINEBRAKE, J., GREEN, E. H., KASIBHATLA, P., EYRING, V. \& LAUER, A. 2007. Mortality from Ship Emissions: A Global Assessment. Environmental Science \& Technology, 41, 8512-8518.

DEKATI. 2010. Dekati FPS-4000, Fine Particle Sampler. Tampere, Finland: Dekati Ltd.

FINLAYSSON-PITTS, B. J. \& PITTS, J. N. 2000. Chemistry of the upper and lower atmosphere, Academic Press.

FRIDELL, E., STEEN, E. \& PETERSON, K. 2008. Primary particles in ship emissions. Atmospheric Environment, 42, 1160-1168.

FU, M., DING, Y., GE, Y., YU, L., YIN, H., YE, W. \& LIANG, B. 2013. Real-world emissions of inland ships on the Grand Canal, China. Atmospheric Environment, 81, 222-229.

GRIMM AEROSOL TECHNIK GMBH \& CO KG 2010. Portable Laser Aerosolspectrometer and Dust Monitor Model 1.108/1.109. In: KG, G. A. T. G. C. (ed.). Ainring, Germany. 
HALlQUiST, A. M., FRIDELl, E., WESTERLUND, J. \& HALLQUIST, M. 2013. Onboard measurements of nanoparticles from a SCR-equipped marine diesel engine. Environ Sci Technol, 47, 773-80.

HINDS, W. C. 1999. Aerosol technology, John Wiley \& Sons, Inc.

IMO 2009. Revised MARPOL Annex VI and NOx Technical Code 2008: Regulations for the prevention of air pollution from ships .

ISAKSON, J., PERSSON, T. A. \& SELIN LINDGREN, E. 2001. Identification and assessment of ship emissions and their effects in the harbour of Göteborg, sweden. Atmospheric Environment, 35, 3659-3666.

KASPER, A., AUfDENBlATTEN, S., FORSS, A., MOHR, M. \& BURTSCHER, H. 2007. Particulate Emissions from a Low-Speed Marine Diesel Engine. Aerosol Science and Technology, 41, 24-32.

KITTELSON, D. B. 1998. Engines and nanoparticles: A review. Journal of Aerosol Science, 29, 575588.

LACK, D. A. \& CORBETT, J. J. 2012. Black carbon from ships: a review of the effects of ship speed, fuel quality and exhaust gas scrubbing. Atmospheric Chemistry and Physics, 12, 3985-4000.

LACK, D. A., CORBETT, J. J., ONASCH, T., LERNER, B., MASSOLI, P., QUINN, P. K., BATES, T. S., COVERT, D. S., COFFMAN, D., SIERAU, B., HERNDON, S., ALlAN, J., BAYNARD, T., LOVEJOY, E., RAVISHANKARA, A. R. \& WILlIAMS, E. 2009. Particulate emissions from commercial shipping: Chemical, physical, and optical properties. Journal of Geophysical Research, 114.

LYYRÄNEN, J., JOKINIEMI, J., KAUPPINEN, E. I. \& JOUTSENSAARI, J. 1999. Aerosol characterisation in medium-speed diesel engines operationg with heavy fuel oils. Journal of Aerosol Science, 30, 771-784.

MAZZEI, F., D'AlESSANDRO, A., LUCARELli, F., NAVA, S., PRATI, P., VALli, G. \& VECCHI, R. 2008. Characterization of particulate matter sources in an urban environment. Sci Total Environ, 401, 81-9.

MOLDANOVÁ, J., FRIDELl, E., POPOVICHEVA, O., DEMIRDJIAN, B., TISHKOVA, V., FACCINETTO, A. \& FOCSA, C. 2009. Characterisation of particulate matter and gaseous emissions from a large ship diesel engine. Atmospheric Environment, 43, 2632-2641.

MOLDANOVÁ, J., FRIDELL, E., WINNES, H., HOLMIN-FRIDELL, S., BOMAN, J., JEDYNSKA, A., TISHKOVA, V., DEMIRDJIAN, B., JOUlie, S., BLADT, H., IVLEVA, N. P. \& NIESSNER, R. 2013. Physical and chemical characterisation of PM emissions from two ships operating in European Emission Control Areas. Atmospheric Measurement Techniques, 6, 3577-3596.

PARK, K., CAO, F., KITTELSON, D. \& MCMURRY, P. H. 2003. Relationship between Particle Mass and Mobility for Diesel Exhaust Particles. Environ Sci Technol, 37, 577-583.

PETTERSSON, J. B. C., KOVACEVIK, B., WAGNER, A., BOMAN, J. \& LAURSEN, J. 2011. Elemental composition of fine particulate matter (PM2.5) in Skopje, FYR of Macedonia. $X$ Ray Spectrometry, 40, 280-288.

PETZOLD, A., LAUER, P., FRITSCHE, U., HASSELBACH, J., LICHTENSTERN, M., SCHLAGER, H. \& FLEISCHER, F. 2011. Operation of marine diesel engines on biogenic fuels: modification of emissions and resulting climate effects. Environ Sci Technol, 45, 10394400.

POPE, C. A. \& DOCKERY, D. W. 2006. Health Effects of Fine Particulate Air Pollution: Lines that Connect. Air \& Waste Management Association, 56, 709-742.

POPOVICHEVA, O., KIREEVA, E., SHONIJA, N., ZUBAREVA, N., PERSIANTSEVA, N., TISHKOVA, V., DEMIRDJIAN, B., MOLDANOVA, J. \& MOGILNIKOV, V. 2009. Ship particulate pollutants: characterization in terms of environmental implication. $J$ Environ Monit, 11, 2077-86.

SALO, K., HALLQUIST, M., JONSSON, Å. M., SAATHOFF, H., NAUMANN, K. H., SPINDLER, C., TILLMANN, R., FUCHS, H., BOHN, B., RUBACH, F., MENTEL, T. F., MÜLLER, L., REINNIG, M., HOFFMANN, T. \& DONAHUE, N. M. 2011. Volatility of secondary organic aerosol during $\mathrm{OH}$ radical induced ageing. Atmospheric Chemistry and Physics, 11, 1105511067. 
The final version of this article is published in Atmospheric Environment in 2015, vol. 101 pages 65-71

STONE, R. 2012. Introduction to Internal Combustion Engines, England, Palgrave Macmillan.

TSI 2006. Model 3090 Engine Exhaust Particle Sizer Spectrometer, Operation and Service Manual, P/N 1980494, Revision E. USA.

USHAKOV, S., VALLAND, H., NIELSEN, J. B. \& HENNIE, E. 2012. Particulate emission characteristics from medium-speed marine diesel engines. PACIFIC 2012 International Maritime Conference. Sydney, Australia.

USHAKOV, S., VALLAND, H., NIELSEN, J. B. \& HENNIE, E. 2013. Particle size distributions from heavy-duty diesel engine operated on low-sulfur marine fuel. Fuel Processing Technology, 106, 350-358.

VIRTANEN, A., RISTIMÄKI, J., MARJAMÄKI, M., VAARASLATHI, K. \& KESKINEN, J. 2002. Effective Density of Diesel Exhaust Particles as a Function of Size. SAE Technical Paper Series, 2002-01-0056.

WINNES, H. \& FRIDELL, E. 2010. Emissions of NO(X) and particles from manoeuvring ships. Transportation Research Part D-Transport and Environment, 15, 204-211. 
The final version of this article is published in Atmospheric Environment in 2015, vol. 101 pages 65-71

\section{Supplementary Information}

\section{Characterization of particles from a marine engine operating at}

\section{low loads}

Maria Anderson, Kent Salo, Åsa M. Hallquist and Erik Fridell

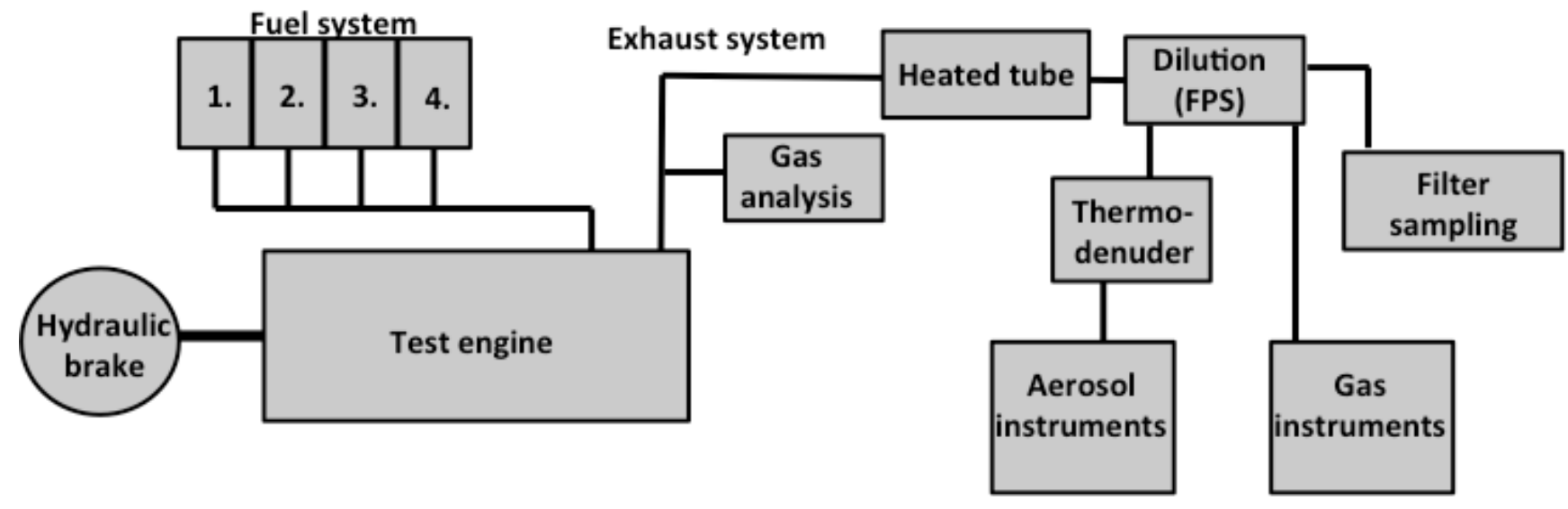

Figure S1: Illustration of the experimental set-up. The thermodenuder (TD) can be bypassed. The heated tube was used in the MK3, HFO and MDO experiments.

Table S1: Data considering the dilution conditions and dilution ratios during the measurements. T1 represents the temperature of the dilution air at the sampling point, T3 is the temperature upstream the ejector (i.e. secondary diluter), T4 is the temperature downstream the ejector and TH11 is the dilution air temperature. The actual dilution ratio (DR) was calculated from the measured concentration of NO before and after the FPS, DRFPS shows the DR reported by the FPS, PD DR is the dilution by the primary diluter (PD), ED DR is the dilution by the ejector diluter (ED, i.e. secondary diluter). For MK3 the actual DR was calculated as described in the method section in the article.

\begin{tabular}{ccccccccccccc} 
& Load & $\begin{array}{l}\text { Actual } \\
\text { DR }\end{array}$ & $\begin{array}{l}\text { DR- } \\
\text { FPS }\end{array}$ & $\begin{array}{l}\text { PD } \\
\text { DR }\end{array}$ & $\begin{array}{l}\text { ED } \\
\text { DR }\end{array}$ & $\begin{array}{l}\text { PD } \\
\text { flow } \\
(\mathbf{l} / \mathbf{m i n})\end{array}$ & $\begin{array}{l}\text { ED } \\
\text { flow } \\
(\mathbf{l} / \mathbf{m i n})\end{array}$ & $\begin{array}{l}\text { T1 } \\
\left({ }^{\circ} \mathbf{C}\right)\end{array}$ & $\begin{array}{l}\text { T3 } \\
\left({ }^{\circ} \mathbf{C}\right)\end{array}$ & $\begin{array}{l}\text { T4 } \\
\left({ }^{\circ} \mathbf{C}\right)\end{array}$ & $\begin{array}{l}\text { TH11 } \\
\left({ }^{\circ} \mathbf{C}\right)\end{array}$ & $\begin{array}{l}\text { Q- } \\
\text { sample } \\
(\mathbf{l} / \mathbf{m i n})\end{array}$ \\
\hline MK1 & $35 \%$ & 53.5 & 35.4 & 4.3 & 8.2 & 11.8 & 100.2 & 108.1 & 148.2 & 41.2 & 332.7 & 3.4 \\
& $25 \%$ & 53.8 & 35.6 & 4.4 & 8.2 & 11.8 & 100.1 & 96.6 & 143.8 & 39.9 & 334.4 & 3.4 \\
& $10 \%$ & 62.8 & 36.1 & 4.4 & 8.2 & 11.9 & 99.9 & 100.3 & 142.2 & 39.4 & 326.0 & 3.3 \\
& & & & & & & & & & & & \\
& Idle & 79.4 & 42.1 & 5.0 & 8.4 & 11.7 & 99.8 & 158.5 & 159.0 & 40.2 & 312.8 & 2.9
\end{tabular}


The final version of this article is published in Atmospheric Environment in 2015, vol. 101 pages 65-71

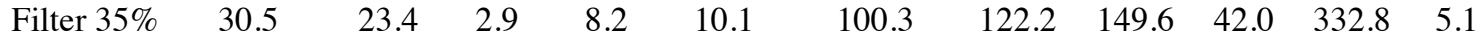

\begin{tabular}{|c|c|c|c|c|c|c|c|c|c|c|c|c|}
\hline \multirow[t]{5}{*}{ MK3 } & $35 \%$ & 27.3 & 21.1 & 2.5 & 8.3 & 9.4 & 98.9 & 189.5 & 150.9 & 43.9 & 407.4 & 5.7 \\
\hline & $25 \%$ & 27.7 & 21.4 & 2.6 & 8.3 & 9.3 & 98.9 & 189.6 & 150.9 & 44.5 & 314.4 & 5.6 \\
\hline & $10 \%$ & 28.0 & 21.6 & 2.6 & 8.4 & 9.3 & 99.2 & 189.0 & 150.6 & 45.5 & 314.3 & 5.5 \\
\hline & Idle & 28.7 & 22.1 & 2.6 & 8.4 & 9.2 & 99.2 & 184.4 & 146.5 & 45.2 & 314.4 & 5.4 \\
\hline & Filter $35 \%$ & 28.9 & 22.3 & 2.6 & 8.5 & 9.3 & 99.1 & 190.4 & 149.9 & 44.9 & 316.3 & 5.4 \\
\hline \multirow[t]{5}{*}{ HFO } & $35 \%$ & 52.0 & 36.1 & 4.2 & 8.5 & 11.2 & 100.2 & 125.6 & 147.9 & 42.8 & 318.1 & 3.3 \\
\hline & $25 \%$ & 49.6 & 37.6 & 4.4 & 8.6 & 11.2 & 100.2 & 123.8 & 148.3 & 41.8 & 318.9 & 3.2 \\
\hline & $10 \%$ & 25.4 & 32.9 & 3.8 & 8.7 & 10.5 & 100.1 & 126.5 & 150.9 & 40.9 & 319.2 & 3.6 \\
\hline & Idle & 21.5 & 35.1 & 4.0 & 8.8 & 10.3 & 100.0 & 123.9 & 150.6 & 40.9 & 321.2 & 3.4 \\
\hline & Filter $35 \%$ & 51.9 & 36.2 & 4.3 & 8.5 & 11.2 & 100.3 & 125.6 & 149.9 & 43.5 & 320.9 & 3.3 \\
\hline \multirow[t]{5}{*}{ MDO } & $35 \%$ & 52.5 & 40.2 & 4.8 & 8.4 & 11.9 & 99.7 & 194.4 & 151.3 & 37.3 & 305.1 & 3.0 \\
\hline & $25 \%$ & 39.6 & 34.4 & 3.9 & 8.8 & 10.6 & 99.8 & 236.7 & 174.3 & 42.4 & 303.5 & 3.5 \\
\hline & $10 \%$ & 25.6 & 34.9 & 4.0 & 8.8 & 10.6 & 99.8 & 235.9 & 174.3 & 42.4 & 303.7 & 3.4 \\
\hline & Idle & 21.9 & 37.1 & 4.2 & 8.9 & 10.5 & 99.7 & 235.2 & 175.5 & 42.7 & 303.1 & 3.2 \\
\hline & Filter $35 \%$ & 29.6 & 23.5 & 2.7 & 8.8 & 9.0 & 99.9 & 242.7 & 186.1 & 45.7 & 304.6 & 5.1 \\
\hline
\end{tabular}

Table S2: Number fraction remaining (NFR) and mass fraction remaining (MFR) of emitted particles at $300{ }^{\circ} \mathrm{C}$ for different loads and fuel types for total particle concentration, nanoparticles (NP) and particles $>50 \mathrm{~nm}(\mathrm{Dp}$ $>50 \mathrm{~nm})$.

\begin{tabular}{|c|c|c|c|c|c|c|c|c|c|c|c|c|c|}
\hline & \multirow[t]{2}{*}{ Load } & \multicolumn{3}{|c|}{ MK1* } & \multicolumn{3}{|c|}{ MK3 } & \multicolumn{3}{|c|}{ HFO } & \multicolumn{3}{|c|}{ MDO } \\
\hline & & Total & $\mathbf{N P}$ & $\begin{array}{c}\text { Dp }>50 \\
\mathbf{n m}\end{array}$ & Total & $\mathbf{N P}$ & $\begin{array}{c}\text { Dp }>50 \\
\text { nm }\end{array}$ & Total & $\mathbf{N P}$ & $\begin{array}{c}\text { Dp }>50 \\
\mathbf{n m}\end{array}$ & Total & $\mathbf{N P}$ & $\begin{array}{c}\text { Dp }>50 \\
\text { nm }\end{array}$ \\
\hline \multirow[t]{4}{*}{ NFR (\%) } & $35 \%$ & 98 & 101 & 95 & 92 & 95 & 87 & 73 & 75 & 61 & $39^{*}$ & $38^{*}$ & $89^{*}$ \\
\hline & $25 \%$ & 94 & 97 & 90 & 99 & 101 & 96 & 1 & 0.8 & 94 & 136 & 80 & 93 \\
\hline & $10 \%$ & 95 & 101 & 85 & 104 & 111 & 90 & 3 & 2 & 86 & 92 & 96 & 78 \\
\hline & Idle & 54 & 48 & 103 & 108 & 109 & 98 & 1 & 1 & 76 & 100 & 110 & 103 \\
\hline \multirow[t]{4}{*}{ MFR (\%) } & $35 \%$ & 93 & 103 & 91 & 88 & 90 & 84 & 47 & 108 & 47 & 82 & $94 *$ & $89 *$ \\
\hline & $25 \%$ & 85 & 96 & 83 & 94 & 100 & 91 & 75 & 1 & 94 & 95 & 92 & 92 \\
\hline & $10 \%$ & 79 & 100 & 76 & 84 & 102 & 82 & 106 & 13 & 127 & 83 & 93 & 80 \\
\hline & Idle & 99 & 70 & 101 & 94 & 107 & 94 & 40 & 3 & 82 & 93 & 104 & 87 \\
\hline
\end{tabular}

\footnotetext{
* data from measurements without heated tube.
} 